\title{
Is gluten free and casein free GFCF diet effective for individuals with autism?
}

\author{
Indah S. Widyahening, ${ }^{1}$ Raden I. Ismail ${ }^{2}$ \\ ${ }^{1}$ Department of Community Medicine, Faculty of Medicine University of Indonesia, Jakarta, Indonesia \\ ${ }^{2}$ Department of Psychiatry, Faculty of Medicine University of Indonesia, Jakarta, Indonesia
}

\begin{abstract}
Abstrak
Latar belakang: Walaupun etiologi autistic spectrum disorder (ASD) belum diketahui dengan jelas, berbagai jenis terapi telah ditawarkan. Salah satu terapi yang paling popular adalah diet bebas glutein dan casein (Gluten Free and Casein Free - GFCF).

Metode: Dilakukan pencarian literatur secara terstruktur melalui internet pada Pubmed dan Cochrane library. Judul dan abstrak sitasi yang ditemukan kemudian ditapis berdasarkan kriteria seleksi yang telah ditentukan sebelumnya. Critical appraisal dilaksanakan berdasarkan kriteria standar mengenai relevansi, validitas, dan levels of evidence.

Hasil: Berdasarkan relevansinya, hanya empat dari dua belas artikel yang bisa digunakan. Satu berupa systematic review dan tiga randomized controlled trial (RCT). Ditemukan beberapa masalah pada metodologi yang bisa menimbulkan risiko over-estimasi pada efek seperti teknik randomisasi yang kurang baik dan drop-out selektif. Jumlah subjek yang kecil dan waktu intervensi yang pendek juga bisa menimbulkan risiko under-estimasi. Perbaikan minimal maupun sedang ditemukan pada beberapa luaran yang diukur seperti gejala autistik secara keseluruhan, isolasi sosial, serta kemampuan dalam berkomunikasi dan berinteraksi. Perbedaan yang tidak bermakna juga ditemukan pada beberapa luaran seperti perilaku individu serta fungsi kognitif dan motorik.
\end{abstract}

Kesimpulan: Penelitian yang ada saat ini belum dapat memberikan bukti yang cukup kuat dan terpercaya untuk menyarankan penggunaan diet GFCFs sebagai terapi pada pasien autisme. (Med J Indones 2011; 20:114-8)

\begin{abstract}
Background: Even though the etiology of autistic spectrum disorder (ASD) has not been clearly known, various types of therapies have been offered. One of the most popular therapies is Gluten Free and Casein Free Diet - GFCF diet.

Methods: A structured internet literature search was conducted using Pubmed and Cochrane library. Titles and abstracts were screened using predetermined selection criteria. Critical appraisal was conducted based on standard criteria for relevance, validity, and levels of evidence.

Results: Based on relevance, only four out of twelve selected articles can be used; one is a systematic review and three randomized controlled trials (RCTs). Several methodological problems which could lead to over-estimation of the effect were found in the studies including poor randomization and selective drop-out. Risk of under-estimation of report due to small number of participants and in-adequate duration of intervention was also found. Small to moderate improvement were found in some outcome measured including overall autistic traits, social isolation, and the ability in communication and interaction. However, insignificant differences also found in some area such as individual's behavior, cognitive and motor function.
\end{abstract}

Conclusion: Available studies fail to provide sufficiently credible and strong evidence to recommend the practice of GFCF diet in treating autism. (Med J Indones 2011; 20:114-8)

Key words: autism, gluten free and casein free diet

The increase of autism or autistic spectrum disorder (ASD) cases in Indonesian children has raised significant awareness of the community. Until now, the etiology of autism is not clearly known, yet numerous types of therapies have been offered in treating autism. One therapy is to eliminate food which has gluten and casein in their ingredients or gluten free and casein free diet - GFCF diet.

The theoretical base for GFCF diet is that there is an incomplete chemical breakdown of gluten and casein originating from food during digestion, resulting an increase in the amount of opioid peptides. ${ }^{1,2}$ The effect of increased intestinal permeability, which is believed to be found in people diagnosed with autism, allows the opioid peptides to get through the blood circulation and moves across blood-brain barrier. Later, the opioid peptides affect the endogenous opiate system and neurotransmission within the central nervous system causing the autistic symptoms. By not eating food composed of gluten and casein, which is the main principle of GFCF diet, the proposed process is hopefully not present and, thereafter the symptoms of autism.

We studied the effectiveness of GFCF diet as a therapy for autism especially in improving individual's behavior, cognitive function, and social interaction of autistic children by using an evidence-based methodology. ${ }^{3}$ 


\section{METHODS}

Online literature research was done on two major online health and medicine databases; PubMed and Cochrane library which are currently presumed to be the most important. The keywords used are "“autism OR autistic' AND diet." The citations generated in the first search were then screened by the titles and abstracts, followed by screening of the full-text based on the predetermined inclusion and exclusion criteria. Inclusion criteria comprised of: (1) Research on individuals who were diagnosed with autism or autistic spectrum disorder (ASD), (2) The intervention is gluten free and casein free (GFCF) diet, (3) Research design are randomized controlled trial (RCT) or systematic review. Articles which are not written in English language were excluded.

Critical appraisal was performed on the selected articles to assess its quality based on suitable criteria. The criteria which used to assess RCTs were; recruitment whether it sufficiently represents the target population or not; allocation - whether it is random or not; was the randomization maintained at every aspect of the research; and does the measurement was done in blinded or objective manner? All are abbreviated into RAMMbo. Furthermore, for the systematic review article, the critical appraisal criteria comprised of "Question, Find, Appraise, and Synthesize” (QFAS). ${ }^{4}$ The separate investigations were conducted independently by the two authors, and a discussion was carried out should there be a disagreement in quality assessment.

\section{RESULTS}

An initial search conducted on August 2010 yielded 151 citations from Pubmed and one from Cochrane. Further selection based on inclusion and exclusion criteria finally resulted four articles which were considered most relevant. No non-English articles were found during the search. Among those articles, one is Cochrane systematic review by Millward et al, 2008 and three are randomized controlled trials (RCT) by Knivsberg, 2002 , Elder, 2006, and Whiteley, 2010. Millward's systematic review only found two RCTs which could be included; those by Knivsberg and Elder. ${ }^{5-8}$

Critical appraisal on the three RCTs as shown in table 1, found some methodological problems which could lead to bias in its result. A High dropout rate, as found in the study by Whiteley et $\mathrm{al}^{8}$, may result in biased outcome. In particular when this is selective drop-out, i.e when those without any experienced of effect of treatment leave the study. The selective drop-out could be related to the awareness of the parents of the treatment being received (single blind study) which is highly influential for patient reported outcomes which in the end lead to over-estimation of the reported effect.

Table 1. Critical appraisal of the randomized controlled trials included in this report.

\begin{tabular}{|c|c|c|c|}
\hline Parameters & Whiteley, 2010 & Elder, 2006 & Knivsberg, 2002 \\
\hline Subjects & $\begin{array}{l}72 \text { subjects, } \\
38 \text { in diet group and } 34 \text { in control group }\end{array}$ & 13 subjects, divided in to two groups & 10 subjects in each group \\
\hline Randomized & $\begin{array}{l}\text { Quote: random allocation, stratified } \\
\text { for age and VABS composite scores. } \\
\text { Randomization methods not stated }\end{array}$ & $\begin{array}{l}\text { Randomized cross-over design. } \\
\text { Randomization methods not stated }\end{array}$ & $\begin{array}{l}\text { Quote: the children were pair wise } \\
\text { matched on } \\
\text { severity of autistic symptoms as well as } \\
\text { age, and cognitive level. They were then } \\
\text { randomly selected to a diet or a control } \\
\text { group. } \\
\text { Randomization methods not stated. }\end{array}$ \\
\hline Allocation concealment & $\begin{array}{l}\text { Quote: a statistician, not involved in the } \\
\text { study conduct the randomization }\end{array}$ & Not stated & Not stated \\
\hline $\begin{array}{l}\text { Were the group similar at the } \\
\text { trial's start }\end{array}$ & $\begin{array}{l}\text { Table } 1 \text { shows similar score between diet } \\
\text { group and non diet group at baseline }\end{array}$ & No baseline data presented & $\begin{array}{l}\text { Quote: the children were pair wise } \\
\text { matched on } \\
\text { severity of autistic symptoms as well as } \\
\text { age, and cognitive level. }\end{array}$ \\
\hline $\begin{array}{l}\text { Were the groups treated } \\
\text { equally? }\end{array}$ & $\begin{array}{l}\text { All participants underwent a } \\
\text { comprehensive behavioural and } \\
\text { psychometric assessment at the Center for } \\
\text { Autisme }\end{array}$ & $\begin{array}{l}\text { All procedure were conducted similarly } \\
\text { in both groups }\end{array}$ & $\begin{array}{l}\text { All procedure were conducted similarly } \\
\text { in both groups }\end{array}$ \\
\hline Adequate follow up? & $\begin{array}{l}\text { Participants were followed for } 12 \text { months. } \\
\text { At the end of study } 27 \% \text { subjects dropped } \\
\text { from intervention group, and } 11,8 \% \text { from } \\
\text { control group, or } 21 \% \text { in total subjects. }\end{array}$ & $\begin{array}{l}\text { Participants were followed only for } \\
6 \text { weeks and then they cross-over the } \\
\text { intervention. }\end{array}$ & $\begin{array}{l}\text { Follow up duration is one year. } \\
\text { No dropped out reported at the end of } \\
\text { study. }\end{array}$ \\
\hline $\begin{array}{l}\text { Analyzed to the group they } \\
\text { were randomized? }\end{array}$ & $\begin{array}{l}\text { Per-protocol analysis was done instead of } \\
\text { intention to treat analysis }\end{array}$ & $\begin{array}{l}\text { Yes, since no subjects dropped out all } \\
\text { get intervention as intended to. }\end{array}$ & $\begin{array}{l}\text { Yes, since no subjects dropped out all get } \\
\text { intervention as intended to. }\end{array}$ \\
\hline Double blind? & $\begin{array}{l}\text { Single blind, the parents aware of } \\
\text { treatment being received. } \\
\text { Outcome assessment was conducted by } \\
\text { person un-aware of the intervention. }\end{array}$ & $\begin{array}{l}\text { Children, parents, and all of the } \\
\text { investigative team except for the data } \\
\text { manager and dietician were blind to the } \\
\text { dietary order. }\end{array}$ & $\begin{array}{l}\text { Single blind, the project leader did not } \\
\text { know which child belonged to which } \\
\text { group until the formal retesting and } \\
\text { interviews were done. No report whether } \\
\text { those who measured the outcomes aware } \\
\text { of the intervention being received, but it } \\
\text { could be presumed that it is the project } \\
\text { leader who measured the outcomes. }\end{array}$ \\
\hline
\end{tabular}


Elder et al conducted a randomized cross-over design which was relatively short in duration (6 weeks for each intervention phase $)^{7}$ which could lead to an underestimation of the reported effect since the outcome probably need more time to be significantly detected. The statistically non-significant result in this study could be also due to the small statistical power from the small number of patients involved.

Knivsberg et $\mathrm{al}^{6}$ described their randomization technique as pair wise matching of the children by severity of autistic symptoms, age, and cognitive level. They were then randomly selected to a diet or a control group. The method of selection of the intervention is not specified in their original article. However, a systematic review by Millward et $\mathrm{al}^{5}$ further mentioned that it was conducted by tossing a coin. The whole randomization method being described is actually not a true randomization technique. Pairing the children based on certain characteristics then gives different intervention to each child means that actually there is only one child in each intervention arm. Therefore, this study does not have enough authority to ascertain that the observed result is not due to chance. The intervention outcomes were measured differently in the three studies as shown in table 2. Whiteley et al found significant improvement in the communication area score as measured by “Autism Diagnostic Observation Schedule” (ADOS), social interaction as measured by "Gilliam Autism Rating Scale” (GARS), daily living skill as measured by "Vineland Adaptive Behavioral Scale" (VABS) and inattention and hyperactivity as measured by "Attention Deficit Hyperactivity Disorder-IV” (ADHD-IV) rating scale. ${ }^{8}$ Other areas in the diagnostic tools such as social and repetitive areas of ADOS, communication and stereotyped of GARS, communication and daily living areas of VABS indicated insignificant score improvement after intervention.

The studies by Elder et al and Knivsberg et al reported here were developed from Cochrane systematic review by Millward et al. Knivsberg et al reported three outcomes which show significant difference for GFCF diet compared to the non-diet group as evaluated by DIPAB (standard evaluation instrument used on Danish children). Those outcomes were overall autistic traits, social isolation, and general ability in communication and interaction. Two outcomes showed insignificant difference: cognitive function which was assessed based on "Leiter International Performance Scale" (LIPS), and motor ability which assessed based on "Movement Assessment Battery for Children”. For other outcomes such as resistance to communication, bizarre behavior and linguistic age, the mean difference could not be calculated because the data were skewed. ${ }^{5-7}$ Elder et al found no significant improvements in all outcomes measured including behavior which was evaluated based on "Childhood Autism Rating Scale" (CARS) and "Ecological Communication Orientation (ECO) Language Sampling Summary”. ${ }^{7}$

Table 2. Outcomes of included studies

\begin{tabular}{|c|c|c|c|}
\hline Outcomes & Effect size & $95 \% \mathrm{CI}$ & $\mathbf{p}$ \\
\hline \multicolumn{4}{|l|}{ Whiteley, 2010* } \\
\hline \multicolumn{4}{|l|}{ ADOS } \\
\hline Communication & 0.19 & & 0.002 \\
\hline Social & 0.01 & & $>0.05$ \\
\hline Repetitive & 0.09 & & $>0.05$ \\
\hline \multicolumn{4}{|l|}{ GARS } \\
\hline social interaction & 1.17 & & 0.0001 \\
\hline communication & 0.002 & & 0.05 \\
\hline stereotyped & 0.07 & & $>0.05$ \\
\hline \multicolumn{4}{|l|}{ VABS } \\
\hline Communication & 0.7 & & $>0.05$ \\
\hline Social & 1.34 & & $>0.05$ \\
\hline Daily living & 5.06 & & 0.02 \\
\hline \multicolumn{4}{|l|}{ ADHD-IV } \\
\hline Inattention & 2.09 & & 0.001 \\
\hline Hyperactivity & $0.9 *$ & & 0.02 \\
\hline \multicolumn{4}{|l|}{ Elder, 2006} \\
\hline ECO at week 6 & 1.40 & $-92.61,95.41$ & \\
\hline CARS at week 6 & 2.40 & $-6.66,11.46$ & \\
\hline \multicolumn{4}{|l|}{ Knivsberg, 2002} \\
\hline \multicolumn{4}{|l|}{ DIPAB at 12 months } \\
\hline Autistic traits (social isolation plus bizarre behavior) & -5.60 & $-9.02,-2.18$ & \\
\hline Communication and interaction & 1.70 & $0.50,2.90$ & \\
\hline Social interaction & -3.20 & $-5.20,-1.20$ & \\
\hline
\end{tabular}

*Difference of mean score improvement between the diet group and non-diet group after 12 months (GARS, VABS, ADHD-IV) or 8 months (ADOS) as compared to baseline. 


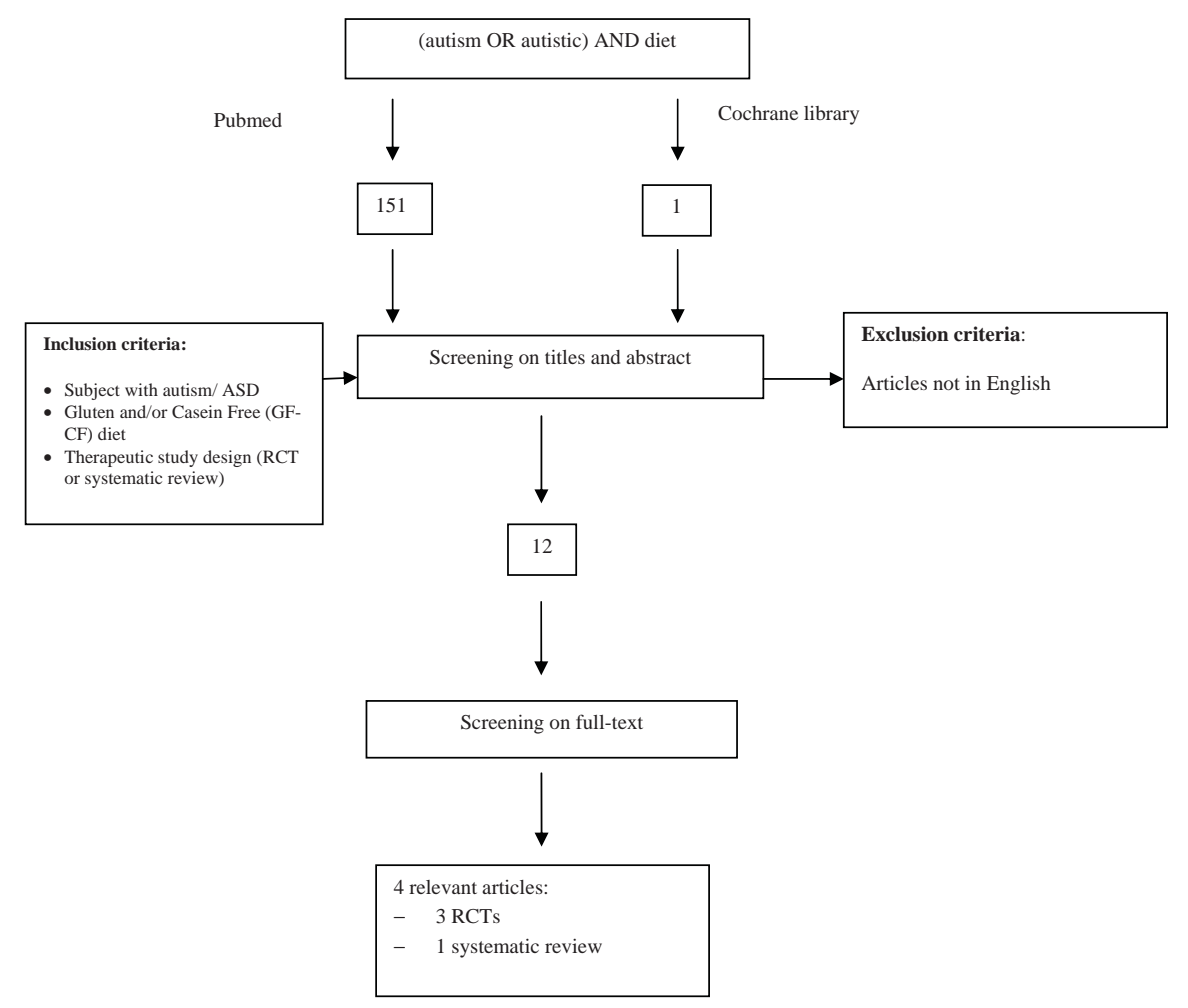

Figure 1. Flowchart of literature research

\section{DISCUSSION}

This is an evidence-based case report currently gaining interest in the publication area along with an increasing application of evidence-based medicine (EBM). It attempts to show all steps of EBM to answer the question "Is GFCF diet effective in treating various symptoms which appeared in children who have ASD?" which is expected as a decision making support on the management of autism in clinical practice. It is expected that all the interventions recommended by the medical practitioners are based on reliable evidence. Considering how popular the GFCF diet in treating ASD, we believe that it is quite a surprise that only three RCTs exist to be assessed. Randomized controlled trial (RCT) is the best research design to prove the effectiveness of an intervention. ${ }^{9}$

The small number of studies found with inconsistent results among it makes it difficult to determine the effectiveness of GFCF diet. Even as a systematic review has been conducted, since it could only involved two studies, the homogenicity in factors such as study's subject, interventions and outcomes was not sufficient so meta-analysis and sensitivity analysis cannot be done. All data gathered are not free from the risk of bias including those resulted from poor randomization, selective drop out, and relatively short duration of study. Further, the rather small number of participants per study increases the risk of false negative outcomes. Variety of effect measures reported in each study with small number of participants will also impedes statistical pooling of the data. Even as there were significant improvement reported in certain outcomes measurement, this actually is rather small to modest. Since most children with ASD have problem in many different aspects, several insignificant results in different measured area which also found within one study means that the effect of this diet to autism as a whole is dubious. Considering all of those weaknesses, until now the evidence to support the decision making regarding the use of GFCF diet in autism management is still inadequate.

Included studies only reported data on benefits. Data on harm, costs or impact on quality of life were not reported. However, it is important to consider that both gluten and casein are common components found in various types of food which is normally consumed by people. The attempt in reducing or eliminating food which contains these components was not uncomplicated and could have required additional cost. Moreover, a risk of malnutrition surfaced because food in reality was not composed of not only one type of nutrient but many. Hence, the limitation of consuming such food can affect less consuming of other types of nutrients which are found in the particular food. 
In conclusion, the practice of GFCF diet on children who have ASD is not supported by sufficiently credible and strong evidence about its benefit. Available studies fail to report potential harm or side effects, as well as the balance between effects and cost. Randomized trials with a large number of participants with better methodology will be required before an evidence based recommendation can be provided about GFCF diet as an approach to treating autism.

\section{REFERENCES}

1. Elder JH. The gluten-free, casein-free diet in autism: An overview with clinical implications. Nutr Clin Pract. 2008; 23(6): 583-8.

2. Shattock P, Kennedy A, Rowell F, Berney T. Role of neuropeptides in autism and their relationships with classical neurotransmitters. Brain Dysfunction. 1990; 3:315-27.

3. Dawes M, Summerskill W, Glasziou P, Cartabellotta A, Martins J, Hopayian K, et al. Sicily statement of evidencebased practice. BMC Med Edu. 2005; 5(1):1-7.
4. Glasziou P, Mar CD, Salisbury J, Evidence-based practice workbook; Bridging the gap between health care research and practice. 2nd ed. Oxford: Blackwell Publishing. 2007 p.125-6.

5. Millward C, Ferriter M, Calver S, Connell-Jones G.Glutenand casein-free diets for autistic spectrum disorder. Cochrane Database Systematic Rev. 2008; 16;(2):CD003498.

6. Knivsberg A, Reichelt KL, Hoien T, A randomised, controlled study of dietary intervention in autistic syndromes. Nutr Neurosci. 2002; 5(4): 251-61.

7. Elder JH, Shankar M, Shuster J, Theriaque D, Burns S, Sherrill L. The gluten-free, casein-free diet in autism: Results of a preliminary double blind clinical trial. J Autism Dev Disord. 2006; 36(3): 413-20.

8. Whiteley P, Haracopos D, Knivsberg A, Reichelt KL, Parlar S, Jacobsen J, et al. The ScanBrit randomised, controlled, singleblind study of a gluten- and casein-free dietary intervention for with autism spectrum disorders. Nutr Neurosci. 2010; 13(2): 87-100.

9. Grobbee D, Hoes A. Clinical epidemiology: Principles, methods, and applications for clinical research. Sudbury: Jones and Bartlett Publishers; 2008. 